\title{
Cytoprotective Effects of Cerium and Selenium Nanoparticles on Heat-Shocked Human Dermal Fibroblasts: An in vitro Evaluation [Corrigendum]
}

\section{Yuan B, Webster $\mathrm{T}$, Roy A. Int $J$ Nanomedicine.} 2016;11:1427-1433.

The authors inadvertently duplicated several images across Figures 4, 5 and 6 on pages 1431 and 1432 in the original publication. Figure $4 \mathrm{Ce}(500 \mu \mathrm{g} / \mathrm{mL}) 37^{\circ} \mathrm{C} 24 \mathrm{~h}$ was duplicated with Figure $5 \mathrm{Ce}(500 \mu \mathrm{g} / \mathrm{mL}) 37^{\circ} \mathrm{C} 48 \mathrm{~h}$; Figure 5 Control $37^{\circ} \mathrm{C} 48 \mathrm{~h}$ was duplicated with Figure 5
Se $37^{\circ} \mathrm{C} 48 \mathrm{~h}$ and Figure $4 \mathrm{Se}(500 \mu \mathrm{g} / \mathrm{mL}) 42^{\circ} \mathrm{C} 24 \mathrm{~h}$ was duplicated with Figure $6 \mathrm{Se} 42^{\circ} \mathrm{C} 72 \mathrm{~h}$.

The correct Figures 4, 5 and 6 are as follows.

The authors have advised that this does not change the conclusion of the paper. $37^{\circ} \mathrm{C} 24 \mathrm{~h}$
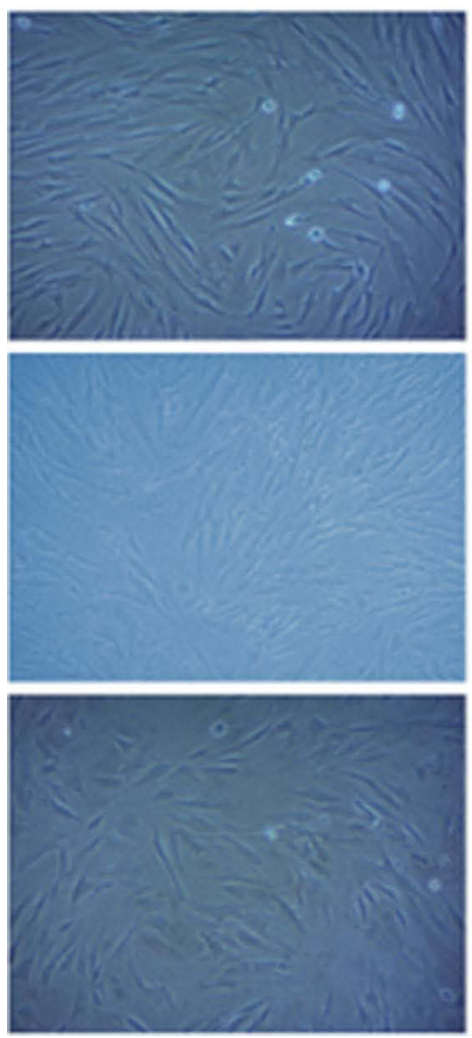

$42{ }^{\circ} \mathrm{C} 24 \mathrm{~h}$
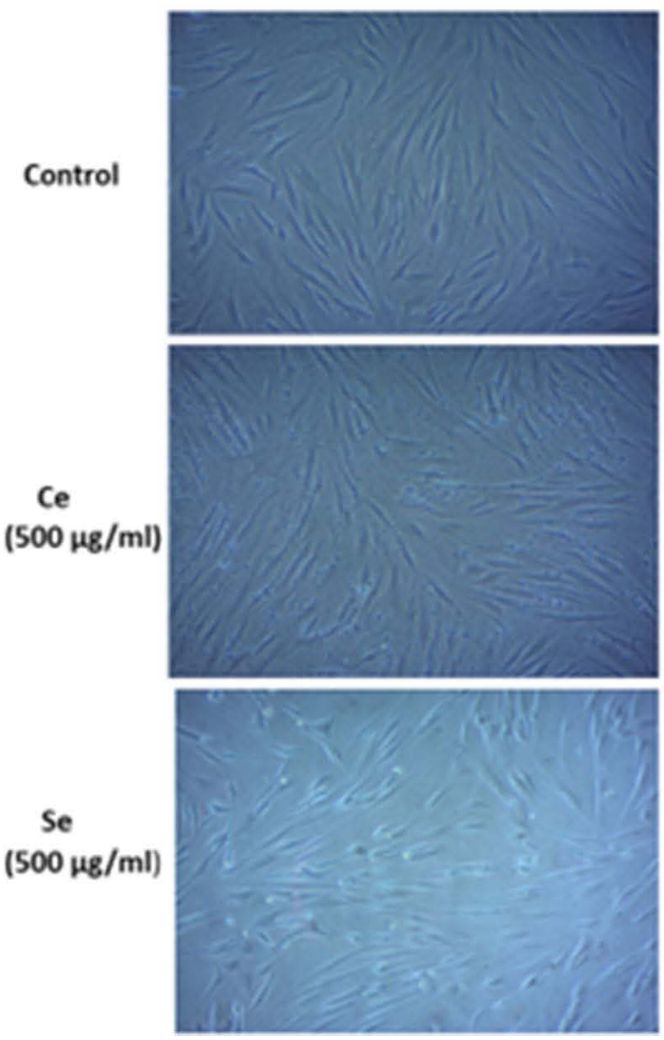

$45^{\circ} \mathrm{C} 24 \mathrm{~h}$
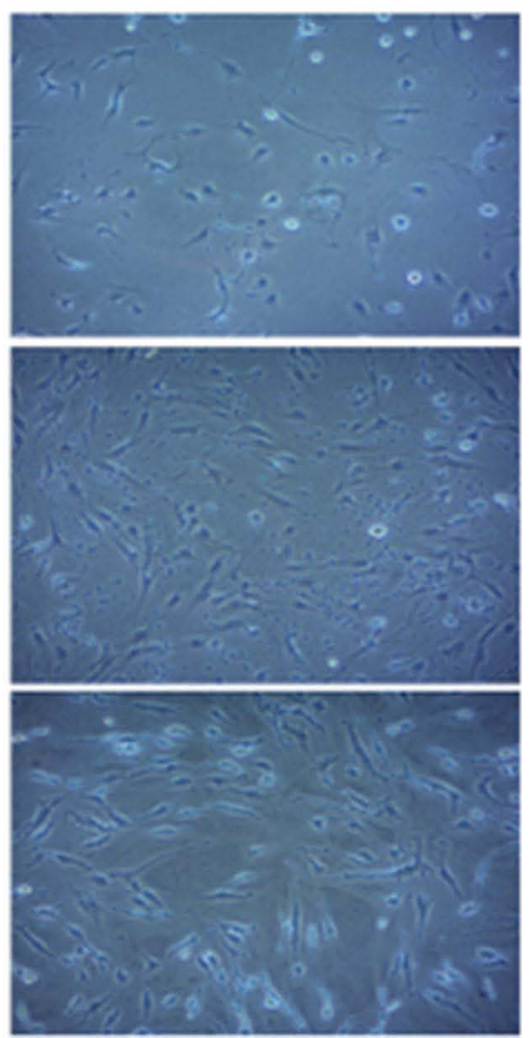

Figure $4 \mathrm{HDF}$ cells preincubated with ceria and selenium NPs $(500 \mu \mathrm{g} / \mathrm{mL}$ for 24 hours $)$ and heat stressed at $37^{\circ} \mathrm{C}, 42^{\circ} \mathrm{C}$, and $45^{\circ} \mathrm{C}$ for I hour. Note: Cells were recovered in fresh medium for 24 hours.

Abbreviations: HDF, human dermal fibroblasts; NPs, nanoparticles; h, hours; Ce, cerium; Se, selenium. 


\section{$37^{\circ} \mathrm{C} 48 \mathrm{~h}$}
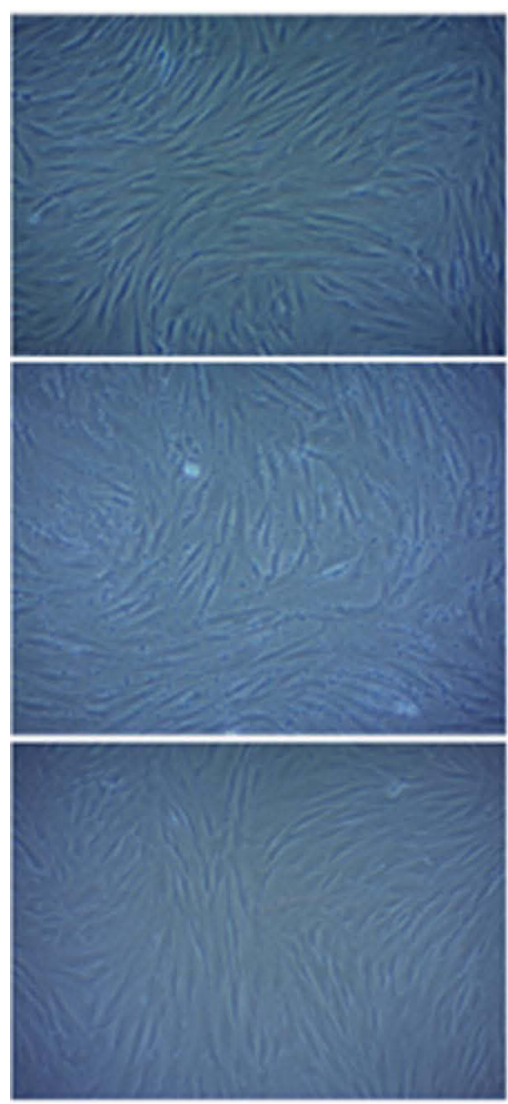

$42^{\circ} \mathrm{C} 48 \mathrm{~h}$
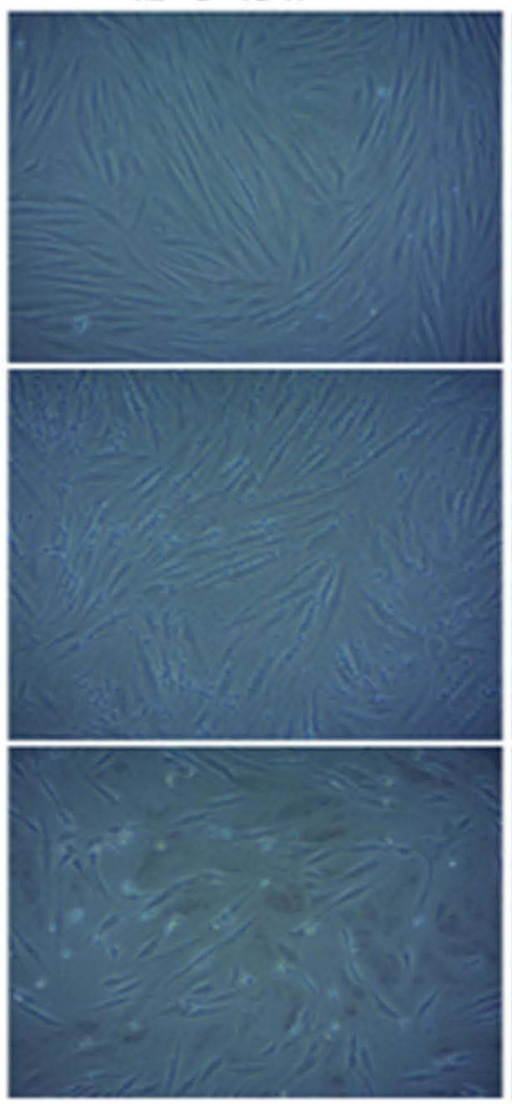

$45^{\circ} \mathrm{C} 48 \mathrm{~h}$
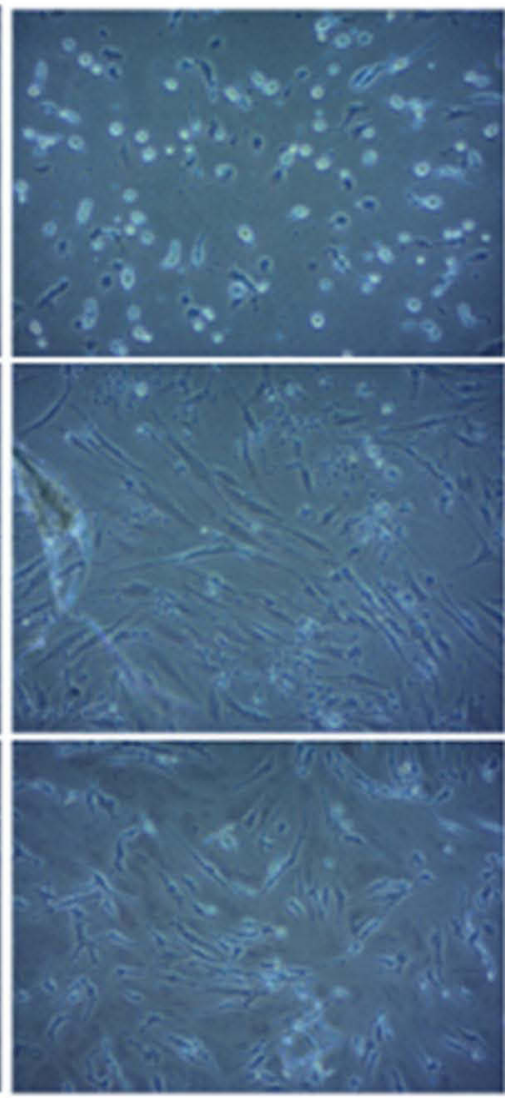

Figure 5 Following preincubation with ceria and selenium NPs $\left(500 \mu \mathrm{g} / \mathrm{mL}\right.$ for 24 hours), cells were heat stressed at $37^{\circ} \mathrm{C}, 42^{\circ} \mathrm{C}$, and $45^{\circ} \mathrm{C}$ for $\mathrm{I}$ hour. Note: Cells were recovered for 48 hours.

Abbreviations: NPs, nanoparticles; h, hours; Ce, cerium; Se, selenium. 
$37^{\circ} \mathrm{C} 72 \mathrm{~h}$
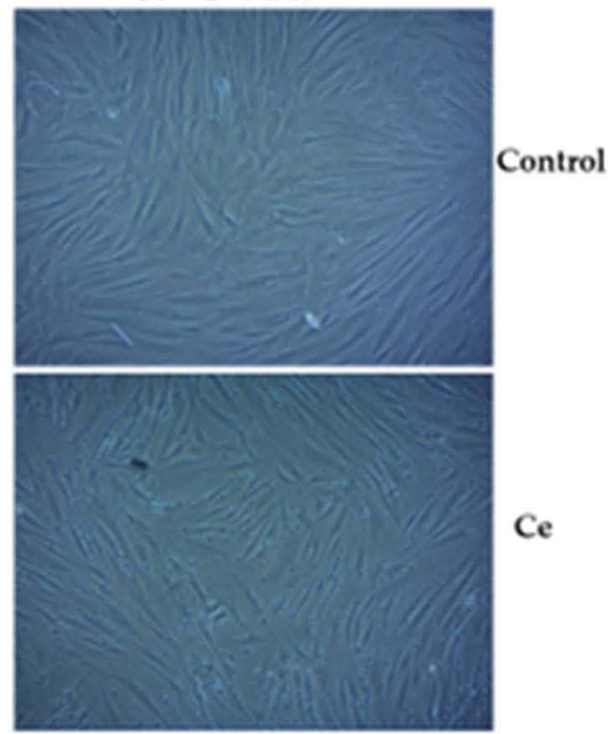

$\mathrm{Ce}$

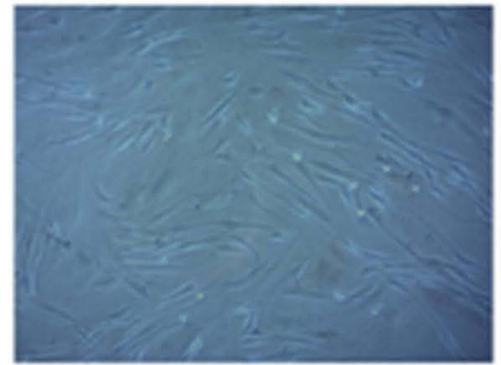

$42{ }^{\circ} \mathrm{C} 72 \mathrm{~h}$
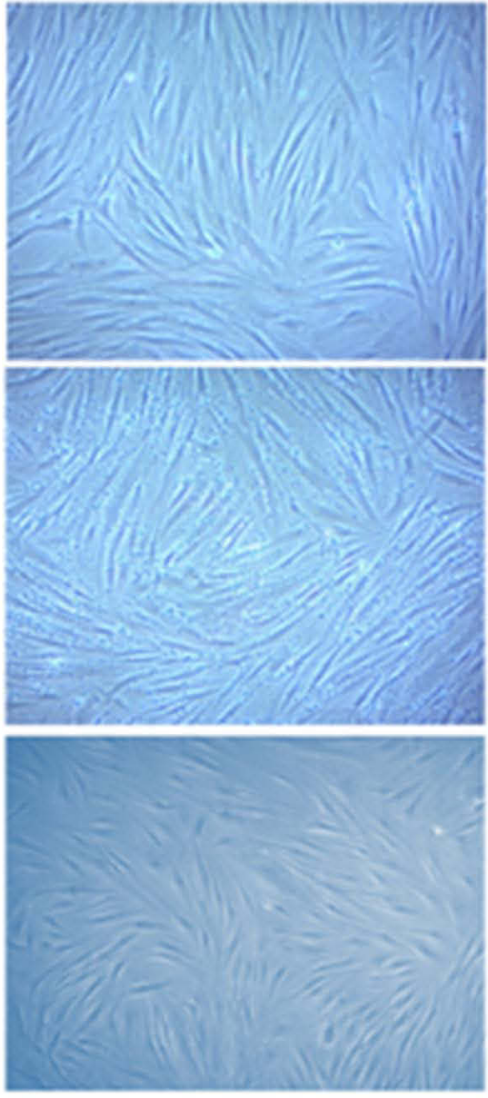

$45^{\circ} \mathrm{C} 72 \mathrm{~h}$
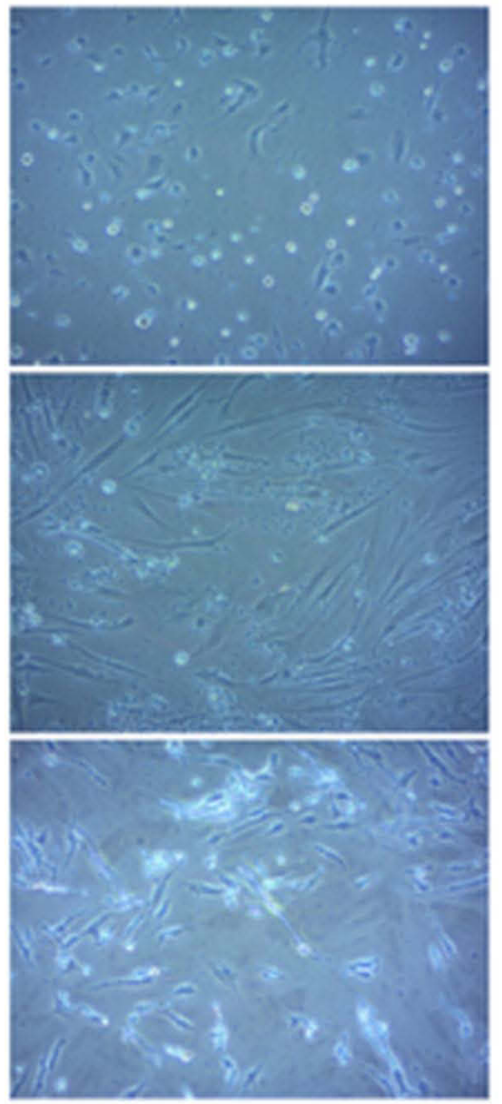

Figure 6 Following preincubation with ceria and selenium NPs $\left(500 \mu \mathrm{g} / \mathrm{mL}\right.$ for 24 hours), cells were heat stressed at $37^{\circ} \mathrm{C}, 42^{\circ} \mathrm{C}$, and $45^{\circ} \mathrm{C}$ for 1 hour. Note: Cells were recovered for 72 hours.

Abbreviations: NPs, nanoparticles; h, hours; Ce, cerium; Se, selenium.

\section{Publish your work in this journal}

The International Journal of Nanomedicine is an international, peerreviewed journal focusing on the application of nanotechnology in diagnostics, therapeutics, and drug delivery systems throughout the biomedical field. This journal is indexed on PubMed Central, MedLine, CAS, SciSearch ${ }^{\mathbb{B}}$, Current Contents ${ }^{\mathbb{B}} /$ Clinical Medicine, $^{2}$
Journal Citation Reports/Science Edition, EMBase, Scopus and the Elsevier Bibliographic databases. The manuscript management system is completely online and includes a very quick and fair peer-review system, which is all easy to use. Visit http://www.dovepress.com/ testimonials.php to read real quotes from published authors. 